\title{
External Possessor Constructions in Indo-European
}

\author{
Silvia Luraghi
}

\begin{abstract}
Two external possessor constructions occur in ancient Indo-European languages: the dative external possessor construction, and the double case construction. They both indicate adnominal possession by means of syntactically independent NPs, and basically refer to inalienable possession. In this article, I analyze the two constructions, describe their meaning and their syntactic properties, and review the comparative evidence for each of them. Neither construction is uniformly attested throughout the Indo-European language family. In addition, the dative external possessor construction seems to be quite unstable over time. Based on the data presented, I conclude that the former can be reconstructed as an original Proto-Indo-European construction, while the latter must be regarded as a language specific construction, with different properties in the languages in which it occurs.
\end{abstract}

\section{$1 \quad$ Introduction}

External possessor constructions have been described in the typological literature as constructions in which two NPs indicate a possessor and a possessum, but are not in a relation of syntactic dependency. Typically, external possessor constructions involve two syntactically independent NPs, each of which can function as an argument of the predicate with which they co-occur, as argued in Payne \& Barshi (1999: 3), who provide the following definition: "constructions in which a semantic possessor-possessum relation is expressed by coding the possessor ... as a core grammatical relation of the verb and in a constituent separate from that which contains the possessum."

Two types of external possessor construction occur in ancient Indo-European languages: one in which the possessor is in the dative, and one involving double case. Homeric Greek offers examples for both constructions: 
(1) Hérēi d' ouk ékhade sthêtos khólon Hera:DAT PTC NEG contain:AOR.3SG breast:NOM wrath:ACC 'Hera's breast could not withhold wrath.' (Hom. Il. 4.24 - Greek)

(2) tón $r^{\prime}$ Oduseùs... bále dourì kórsēn 3SG.ACC PTC Odysseus:NOM hit:AOR.3SG spear:DAT brow:ACC 'Odysseus hit his brow with a spear.' (Hom. Il. 4.501-502 - Greek)

In both sentences we find a nominal expression that indicates a person plus the name of a body part that belongs to this person. In (1), the dative NP Hérēi 'Hera.DAT' refers to the possessor of the body part sthêtos 'breast.NOM', which is the subject of the sentence. Similarly, in (2) the accusative demonstrative tón 'this.ACC' refers to the possessor of the body part kórsēn 'brow.ACC', which is the direct object of the sentence.

In this article, I review the data concerning these two constructions in order to test their reconstructability as a common Proto-Indo-European heritage. I argue that the former should be reconstructed as a Proto-Indo-European construction, in spite of not being as uniformly attested as is usually said in the literature, while the latter most likely cannot.

The article is organized as follows. In Section 2 I describe the dative external possessor construction. After a brief introduction in which I show what types of possessa it usually involves, I review the comparative data from Ancient Indo-European languages (Section 2.1). I then discuss the meaning of the construction, and the semantic role of the external possessor (Section 2.2). In Section 2.3, I contrast the dative external possessor construction with the construction of verbs of depriving. Section 2.4 describes diachronic changes in various Indo-European languages, in which the dative external possessor construction has either been replaced by other constructions, or has arisen as a replacement. In Section 2.5 I discuss the reconstructability of the construction. Section 3 is devoted to double case constructions. I start by describing the double accusative in Homeric Greek (3.1). In Section 3.2 I discuss the meaning of the Greek construction. Then I survey the evidence from other ancient Indo-European languages, except for Hittite and Armenian (3.3). Section 3.4 is devoted to the Hittite and Armenian data concerning double case constructions. In Section 3.5 I discuss the reconstructability of the double case construction based on comparative evidence. Section 4 contains the conclusion. 
External possessor constructions involving the dative are a frequently occurring feature of Indo-European languages, including many modern ones. According to Haspelmath (1999), external possessor constructions of this type are an areal feature of the modern languages of Europe. Concerning the ancient Indo-European languages, this construction has been long recognized and it is exhaustively described in the handbooks. For example Havers (1911) offers an exhaustive description covering all ancient Indo-European languages except Anatolian and Tocharian, which were not known at the time when the book was written. He shows the extent to which different types of possessors could feature in this construction, and the development of the construction over time. He rightly acknowledges the difference between this type of dative, for which he uses the name of dativus sympatheticus, and the beneficiary dative, even though it is not completely clear that all the types of dativus sympatheticus he lists are to be kept apart from beneficiary uses of the dative case. Indeed, the trademark of the dativus sympatheticus according to Havers is that it is equivalent to a genitive or to a possessive pronoun/adjective, and in fact genitive NPs and possessives also occur in the same contexts. This is true for his types (i)-(v) (examples 3-8), while type (vi) (examples 9-10) is slightly different, as equivalent expressions feature various types of spatial NPs or PPs, rather than possessive expressions. Havers' term dativus sympatheticus is often translated as 'dative of affection', or 'dative of interest'. In this article, I will mostly use dativus sympatheticus to refer to it, in order to avoid confusion with other possible functions of the dative.

Below are the six types of dativus sympatheticus according to Havers, with examples from ancient Indo-European languages.

i) The event affects the human body or one of its parts:
(3) minatur
mihi oculos
exurere

threaten:PRS.3SG 1SG.DAT eye:ACC.PL burn_out:INF.PRS

'He's threatening to burn my eyes out.' (Pl. Men. 843 - Latin)

ii) The event affects the spirit or the feelings of a human being:
(4) hós
$m o i$
epôrse
ménos
REL.NOM 1SG.DAT arouse:AOR.3SG strength:ACC
'Who aroused my strength.' (Hom. Il. 20.93 - Greek) 
iii) The event affects personal possessions of a human being, including kinship relations:
(5) ašte komou
bratrŭ
oumŭretŭ
if INDF.DAT brother:NOM die:PRS.3SG
'If somebody's brother dies.' (Luke 20.28 - Old Church Slavic)

iv) Sentences that contain verbs of depriving:
(6) jah saei ni habaip jah patei habaip
and REL.NOM NEG have:PRS.3SG and DEM.NOM have.PRS.3SG
afnimada imma
take:PRS.3SG.P 3SG.DAT

'And he that has not, from him shall be taken even that which he has.' (Mark 4.25 - Gothic)

v) Human relations:
(7) sijai
allaim skalks
be:SBJ.3SG all:DAT.PL slave:NOM
'(That one) will be the slave of all.' (Mark 10.44 - Gothic)
(8) patèr dé moí esti Polúktōr fater:NOM PTC 1SG.DAT be:PRS.3SG Polyctor:NOM 'My father is Polyctor.' (Hom. Il. 24.397 - Greek)

vi) Contexts in which the dative alternates with a locative expression:
(9) oúte tis
oûn moi noûsos
epếluthen
NEG INDF.NOM PTC 1SG.DAT disease:NOM come_upon:AOR.3SG
'Nor did any disease come upon me.' (Hom. Od. 11.200 - Greek)
(10) hōs Aphroditēe êlthen Árēi epíkouros as Aphrodite:NOM come:AOR.3SG Ares:DAT helper:NOM 'As Aphrodite came as Ares' helper.' (Hom. Il. 21.430-431- Greek) ${ }^{1}$

Havers' six categories do not all instantiate the same construction. In this article, I will mainly be concerned with categories (i), (ii), (iii) and (v), which

1 An anonymous reviewer wonders whether this is not an occurrence in which the dative indicates a human relation, as in (7) and (8). In fact, the difference is pretty clear. In (10) it is not said that Aphrodite is Ares' helper, but that she came as helper: in other words, it is the whole phrase epíkouros érkhesthai 'come as helper' that takes a beneficiary dative, which could also be encoded by a prepositional phrase. 
are indeed cases of inalienable possession. The other two categories should be treated differently, for various reasons that I illustrate shortly in this section, and will take up again in Sections 2.3 and 2.4. It is also remarkable that some of the occurrences in category $(\mathrm{v})$ seem better understood as cases of beneficiary dative, as I will show in Section 2.5.

Type (iv) is often treated as containing a dative external possessor (cf. for example Fried 1999, Haspelmath 1999), and it frequently occurs in languages that also feature types (i)-(iii) and (v). However, here I take it as a different construction, as verbs of depriving are ditransitive (see Malchukov et al. 2010). Consequently, I consider the occurrences of a dative third argument with such verbs in the larger framework of language specific ditransitive constructions, and suggest that it be viewed as an extension of the construction of verbs of giving, which, in the same languages, typically take a third argument in the dative. Type (vi) cannot be regarded as instantiating a possessive construction: rather, the dative here has other functions, indicating a participant which is indeed affected by an event, but cannot be understood as a possessor. The examples in Havers (1911) show that the most frequent interpretation of type (vi) datives is beneficiary, as in (10) or, less frequently, experiencer in inchoative experiential situations, as in (9). Notably, in Vedic this type frequently involves nouns rather than pronouns, and it only has a beneficiary interpretation (see below, Section 2.5).

\subsection{Comparative Data}

External possessors in the dative are prototypical possessors, that is, they are animate, most often human. ${ }^{2}$ As I have already remarked above, Havers (1911) gives abundant data for all ancient Indo-European languages except Anatolian and Tocharian, data which indicate that the dative external possessor in the categories (i)-(iii) and (v) was especially frequent for first and second person pronouns, while being less frequent or even unattested depending on the language for third person (demonstrative) pronouns ${ }^{3}$ and other nominal categories.

However, a word of caution must be said concerning whether the occurrence of a dative in this construction in all languages described by Havers is

2 Inanimate possessor can also appear in external possessor constructions in some languages, as long as they are in a part-whole relation with the possessee. See Baldi \& Nuti (2010: 352) on Latin.

3 In ancient Indo-European languages the third person pronoun was in origin a demonstrative, and no dedicated third person pronoun similar to first and second person pronouns can be reconstructed for Proto-Indo-European. 
real. Indeed, as Havers himself acknowledges, it is hard if not impossible to distinguish morphologically the dative from the genitive of first and second person pronouns in some of these languages. In particular, in Sanskrit the enclitic forms $m e$ and $t e$ are both genitive and dative of first and second person singular pronouns. (Likewise, dual and plural clitic personal pronouns do not have distinct forms for the dative and the genitive.) Dative accented forms also exist, which are distinct from genitive forms, i.e. máhyam and túbhyam. Notably, however, they do not occur as dativus sympatheticus (Havers mentions a single occurrence of tubhyam, see below, Section 2.5). So, when Havers (1911: 44) says that the two occurrences in (11) and (12) typically illustrate the distinction between first and second person-dative on the one hand and third person-genitive on the other, one must be aware that synchronically this is not the case.

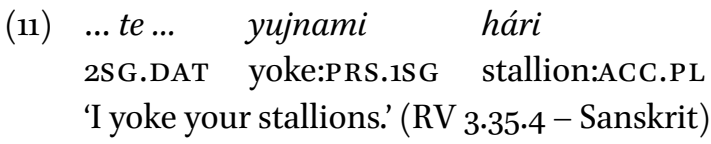

(12) yunjánt asya ... hári... ráthe yoke:PRS.3PL 3SG.GEN stallion:ACC.PL cart:LOC 'They yoke his stallions to the cart.' (RV 1.6.2. - Sanskrit)

Havers (1911: 9-10; 14-17) takes great care in demonstrating that the forms me and $t e$ could function as dative in other constructions, for example with verbs of giving. Crucially, however, with such constructions other nominal categories also occur in the dative, so it is plausible that the clitic forms were synchronically felt as dative. But when we come to the dativus sympatheticus, the complementary distribution of the genitive and the putative dative forms does not support this interpretation: from the synchronic point of view there is no reason to set up a distinction between a dative and a genitive here (cf. also Haudry 1977: 69-70). So, synchronically, the forms $m e$ and $t e$ can be regarded as genitives, an interpretation which is supported by the occurrence of the genitive in this construction with all other types of constituent. The Iranian evidence, too, is hardly compelling. In Old Persian, syncretism of the dative and the genitive was already complete for all types of nominal categories before the time of the written attestations. Avestan, in which the two cases are still separate in the declension of nouns and accented pronouns, provides limited evidence only for Havers' category (v), but crucially not for types (i)-(iii), as, similar to Sanskrit, it features syncretic genitive-dative forms for pronominal clitics. 
From the diachronic point of view, $m e$ and $t e$ go back to Proto-Indo-European * $m o i$ and ${ }^{*} t o i$, which are dative forms. So one could still value the Indo-Iranian evidence, as it could preserve an ancient Proto-Indo-European construction, which was no longer synchronically available for speakers. However, one must also consider the evidence from the languages that were not yet known in Havers' time, that is, Hittite and Tocharian. Concerning the latter, not much can be said, again on account of the merger of the dative and the genitive. Hittite, the oldest attested Indo-European language, offers a quite unexpected picture. In Old Hittite original texts, pronominal datives such as those shown above in the other Indo-European languages do not occur. Instead, a set of possessive enclitics occurs, as shown in examples (13) and (14).

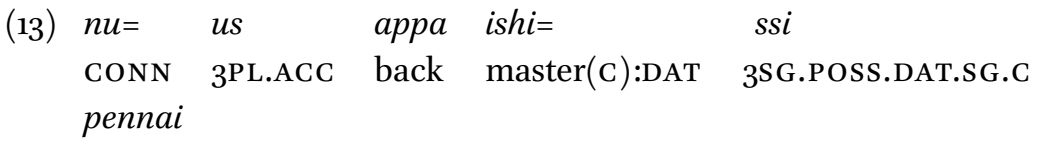

drive:PRS.3SG

'(S)he takes them (= the oxen) back to their (sg.) owner.'

(Laws $§ 79-$ Hittite)

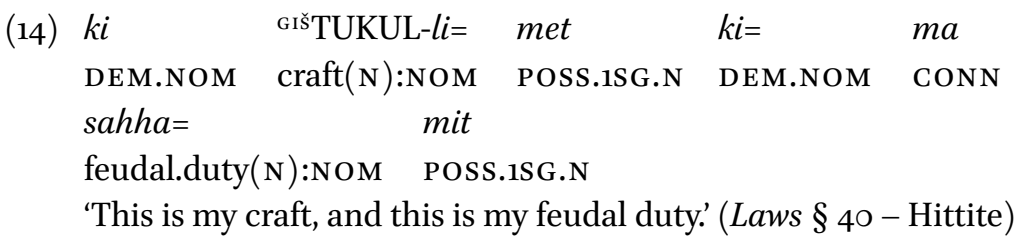

According to Gamkrelidze \& Ivanov (1995: 250-253), possessive enclitics are limited to inalienable possession in Old Hittite. However, examples such as (14) cast some doubts on this hypothesis. Baldi (2002) further mentions occurrences such as halugatalla $(n)=$ tin 'your envoy', and adds that genitive forms of personal pronouns are almost never used in Old Hittite texts, while enclitic possessives are virtually the only items that can express pronominal possession. It thus seems safer not to posit a link between possessive clitics and inalienability. Such clitics also occur as cross-referencing devices with possessive genitives, in a construction that involves both head and dependent marking, as in (15) and (16). ${ }^{4}$

4 Following common transcription conventions for cuneiform languages, capitalized roots (e.g. LUGAL) represent Sumerian logograms, which are separated by a hyphen from the second part of the word, which reproduces Hittite lexical material. This hyphen does not indicate a morpheme boundary, and so has no analogue in the gloss line. 
(15) LUGAL-was aras= mis king:GEN friend(C):NOM 1SG.POsS.NOM.C 'The friend of mine, the king.' (KUB 29.1 i 35 - Hittite)

(16) [laba]rnas LUGAL-as NINDA= san adue[ni $]$ labarna:GEN king:GEN bread(c) 3SG.POSS.ACC.C eat:PRS.1PL [wata $]=$ set $=\quad$ a akueni water(N) 3SG.POSS.ACC.N PTC drink:PRS.1PL

'Let us eat the bread of the Labarna, the king, let us drink his water!' (StBoT25.140, Rev. 5'-6' - Hittite)

In the case of this latter construction a connection with inalienable possession has also been suggested (Garrett 1998). As remarked by Baldi (2002: 32) it is hard to draw universal boundaries of what can be inalienably possessed, and the discussion becomes circular (see further Chappell \& McGregor 1996 for a general discussion of inalienable possession, Kockelman 2009 on linguistic reflexes of inalienable possession, and Heine 1997 on inalienability and the role of body parts). In any case, what is clear even about cross-reference clitics with genitives is that they are not limited to part-whole relations.

As noted above, dative external possessors are not attested in Old Hittite texts written in Old Script (see Güterbock 1983: 75; Luraghi 1997: 23). Some occurrences can be found in later copies of Old Hittite texts, but this does not mean that they existed in the original, due to the widespread and well attested scribal habit of updating the language (see further the discussion of example (55) in Section 3.4). Indeed, dative external possessors appear starting from the Middle Hittite period and are frequent in New Hittite. Examples are (17) and (18).

(17) LÚKÚR $^{\mathrm{MES}}=m u=\quad$ kan LÚ.MĚ̌ arsanatallus DIŠTAR GAŠANenemy-PL 1SG.OBL PTC evious:ACC.PL Istar lady $Y A \quad \check{S} \mathrm{U}-i \quad$ dais

my hand:DAT put:PRT.3SG

'Istar my Lady put in my hand my enemies and those who were envious of me.' (StBoT 24 i 58-59- Hittite)

(18) nasma $=$ ssi $=\quad$ kan garates adantes or 3SG.DAT PTC bowels:NOM.PL eat:PTCP.NOM.PL 'Or (when) its bowels have been eaten.' (KU B 7.1+ i 2 - Hittite) 
As the examples show, this construction closely resembles the dative external possessor construction of the other ancient Indo-European languages: but the chronology within Hittite is puzzling, as it seems to be an independent development out of an older stage, in which possession was expressed differently with respect to the other languages.

\subsection{The Meaning of the Dative External Possessor Construction}

As already remarked, dative external possessors are especially frequent with first and second person pronouns. After his remarks on Sanskrit, Havers (1911: 317-320) argues that this must be true of Indo-European in general, as is shown by the evidence from the other languages. In Homeric Greek, for example, Havers analyzed 550 occurrences with the dative and 395 with either the genitive or a possessive adjective, and found that first and second person pronouns featured 410 times in the first group of occurrences, while occurring only 85 times in the second group (1911: 104; similar data come from Germanic, pp. 274$285 ; 299-300$ and $323-324)$.

Thus, especially for the categories which clearly involve inalienable possession, the pattern of the ancient Indo-European languages in which the dative and the genitive are distinct (with the exception of Anatolian) points toward a split between first and second person pronouns on the one hand, and other nominal categories on the other hand. The dative external possessor was the preferred construction for first and second person pronouns, while other nominal categories most often took genitive possessors or possessive adjectives. Due to the limited number of occurrences, it is hard to gauge the difference between the dative external possessor construction and other constructions. Havers (1911) and Bally (1926), as well as more recent studies such as Fried (1999); König \& Haspelmath (1997) and Haspelmath (1999) highlight the importance of affectedness, or 'interest' in more traditional terms, as a feature of the semantic roles taken by external possessors. However, as remarked by Fried (1999), affectedness is a feature of patients, and external possessors are clearly not patients. In particular, they do not undergo a change of state; in addition, they are high on the animacy hierarchy, while prototypical patients are inanimate. What seems distinctive for external possessors is the possibility of perceiving the effects of an event. König \& Haspelmath (1997) quote examples (19) and (20) from Roldán (1972).
(19) Sus
ojos se
llenaron de
lágrimas
POSS.3SG.PL
eyes REFL
filled.up of tears 

(20) Los ojos se le llenáron de lagrimas the eyes REFL 3SG.DAT filled.up of tears 'His/her eyes filled up with tears.' (Spanish)

Example (19) is appropriate in a situation in which the possessor is not mentally affected, i.e. not because some type of emotion made him/her start weeping: this would be the appropriate situation for (20). The situational context for (19), instead, could be one in which tears are triggered by some mechanical effect, as in the case of a patient being treated during surgery.

It is hard to provide evidence from ancient languages, in which interpretations may be speculative. However, examples (21) and (22) from Homeric Greek might perhaps match the Spanish examples above.

(21) séo d' ostéa púsei ároura keiménou 2SG.GEN PTC bone:ACC.PL rot:FUT.3SG earth:NOM lie:PTCP.PRS.GEN en Troíei

in Troy:DAT

'And your bones shall the earth rot as you lie in the land of Troy.'

(Hom. Il. 4.174-175 - Greek)

(22) grápsen dé hoi ostéon ákhris aikhmè scratch:AOR.3SG PTC 3SG.DAT bone:ACC spear:GEN point:NOM Pouludámantos

Polydamas:GEN

'The spear-point of Polydamas cut to his bone.'

(Hom. Il. 17.599-6oo - Greek)

In (21), which features a genitive possessor (séo 2SG.G EN), reference is made to the bones of a person after his death, and perception by the possessor is ruled out here. In (22), instead, the dative possessor (hoi 2SG.DAT) refers to a living warrior, who perceives the wound.

Being animate, typically human, and being perceivers are features of experiencers, rather than of patients. External possessors are also frequently described as similar to beneficiaries, for example in Haspelmath (1999). Notably, the author highlights the relevance of mental affectedness for external possessors (p. 112). Note however that mental affectedness is not a necessary feature of beneficiaries. Beneficiaries are partially affected by the event in which they take part, in the sense that they must be "capable of making use of the 
benefit bestowed upon them" (Kittilä \& Zuñiga 2010:2), but they do not necessarily perceive the situation when it takes place. Consider example (23).

\section{(23) I baked a cake for Mary.}

In (23) it is not implied that the beneficiary has any consciousness of the prospective benefaction at the time of the event. On the other hand, experiencers are by definition involved in an experience, i.e. they perceive the effects of a situation. Thus, I conclude that the semantic role of dative external possessors is experiencer, rather than beneficiary. This is in accordance with the connection between this construction and inalienable possession. Inalienably possessed entities are conceptualized as parts of the possessor, and an event which affects a part of a human possessor is necessarily perceived by the possessor (see also below, Section 3.2).

\subsection{Verbs of Depriving: Maleficiary Dative}

Let us now turn to the dative with verbs of depriving, which I mentioned briefly in Section 2. Rosén (1959) argues that in Homeric Greek the verb aphaíreō 'take away' takes the dative most frequently when the thing which is stolen from someone is an inalienable possession (four occurrences out of five). ${ }^{5}$ However, this does not seem to be the case in other languages discussed by Havers, such as Latin or various Germanic languages, and it is by no means true of Hittite, in which all ditransitive verbs normally take the dative when the third argument is animate at all language stages (Starke 1977, Luraghi 1986), while types (i)-(iii) of dativus sympatheticus do not occur in the oldest texts (see Section 2.1). Some examples are:

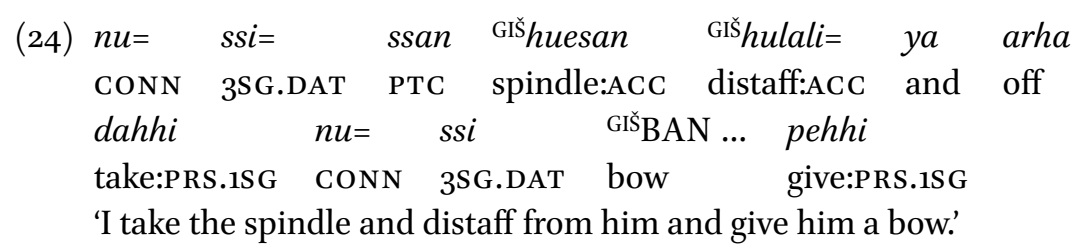

(KUB 9.27 + KUB 7.8 i $23-25$ - Hittite)

5 Verbs of depriving normally took the double accusative in Homer; the cases in which one finds a dative are limited. See Jacquinod (1989: 215, 223-225) and Luraghi \& Zanchi (2018: 28-33). 
(25) Haec prius illi detrahenda auxilia DEM.ACC.PL before 3 SG.DAT take.away:SUP.ACC.PL auxiliary:ACC.PL existimabat quam ipsum bello lacesseret think:IMPF.3SG than same:ACC war:ABL provoke:SBJ.IMPF.3sg 'He thought that these auxiliaries ought to be detached from him before he provoked him to war.' (Caes. Gal. 6.5.5 - Latin)

(26)
pàvogé
tám
séniui
tá óżká steal:AOR.3SG DEM.DAT old.DAT
DEM.ACC.PL goat:ACC.PL 'He stole the goats from the old man.'

(Schl. 128.7, quoted from Havers 1911: 304 - Lithuanian)

(27) dyde him of do:PRT.3sG 3SG.DAT from healse hring gyldenne 'He took away the golden ring from his neck.' (Beowulf 2810 - Old English)

The cross-linguistic distribution of this construction and the type of items involved also differs with respect to types (i)-(iii) and (v) of dativus sympatheticus. As Havers (1911) shows, this construction is infrequent in Homeric Greek and Vedic Sanskrit, in which types (i)-(iii) and (v) are very widespread, while it is very common in Latin, Germanic and Balto-Slavic. In these languages, the construction of verbs of depriving is frequent with all nominal categories, including common nouns, and does not display a split between first and second person pronouns on the one hand, and other nominal categories on the other hand, even though types (i)-(iii) and (v) show this split to varying extents.

In the modern languages of Europe, many of which also feature this construction, it is by no means clear that it only concerns inalienable possession. Consider examples (28) and (29) from Italian.
(28) Gli
hanno
rubato
' auto
3SG.DAT they.have stolen the car
'Somebody stole his car.' (Italian)

(29) Gli

hanno rubato l' auto che gli
they.have stolen the car that 3 SG.DAT heva
Giovanni
Giovanni

lent Giovanni

'Somebody stole from him the car that he had borrowed from Giovanni.' 
While in (28) the default interpretation is that the car belongs to the person indicated by the dative pronoun gli, (29) makes it clear that this implication is not obligatory. Note further that verbs of depriving take the same construction as the verb 'give', as shown in (30).

$\begin{array}{llll}\text { (30) } & \text { Gli } & \text { ho } & \text { dato un libro } \\ \text { DAT.3SG } & \text { I.have given a book } \\ \text { 'I gave him a book.' (Italian) } & \end{array}$

Remarkably, the occurrence of a dative does not per se indicate which construction occurs in a sentence, even in cases in which two sentences contain the same verb, as shown in examples (31) and (32).
(31) Gli
ho
aperto
gli occhi
DAT.3SG I.have opened the eyes
'I opened his eyes.' (Italian)
(32) Gli ho aperto la porta
DAT.3SG I.have opened the door
'I opened the door for him.' (Italian)

In (31) the dative gli indicates a possessor, and has the same function as the external possessor dative in the examples from the ancient Indo-European languages discussed thus far. In (32), the same dative form has a beneficiary function: the different meaning is triggered by the occurrence of an inalienably possessed entity in (31) and one which is not in (32). (Note that this is not limited to dative forms of pronouns: in both examples, one can also replace gli with a prepositional phrase, such as a Giovanni 'to Giovanni.') Even the occurrence of a noun that refers to an entity which is inalienably possessed in normal conditions is not enough to rule out a beneficiary or maleficiary interpretation, if the context makes it possible, as shown in (33).
(33) Il gatto gli ha mangiato il fegato che aveva the cat 3SG.DAT has eaten the liver that had lasciato sul tavolo
'The cat ate the liver that he left on the table on him.' (Italian)

\subsection{The Dative External Possessor Construction and Stability over Time}

Havers (1911) analyzes the development of the dativus sympatheticus and argues that, especially in Greek and in Latin, the construction started declining 
at a rather early time, and was virtually absent toward the end of antiquity, as shown by the data from the New Testament. The absence of the dative external possessor construction in Late Latin is quite striking, as this construction is well attested in the early stages of all Romance languages (Havers 1911: 232). ${ }^{6}$ In fact, it seems that Havers' arguments for increasing limitations of the construction throughout the history of Latin are based on an incorrect evaluation of the style of different authors. According to Baldi \& Nuti (2010: 351) "we find examples in every kind of text and from authors of every age. External possession is differently applied by the authors (e.g., more often in Caesar, less so in Cicero ...), and it strengthens with time." Concerning Late Latin, the authors cite an occurrence from the Peregrinatio Egeriae (6th century CE, p. 352). In addition, while Havers claims that the Latin New Testament does not feature the construction, a cursory exam of first and second person singular pronouns limited to the four Gospels shows that this is not the case. In (34), a dative external possessor matches a genitive pronoun in the Greek text:

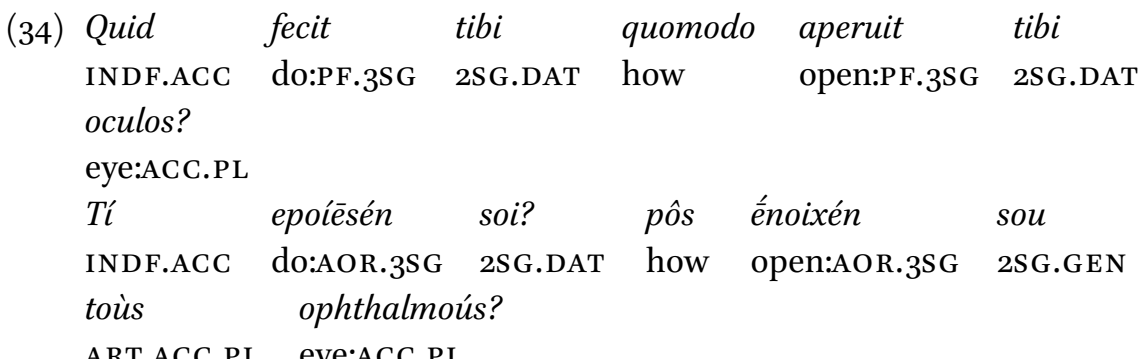

'What did he do to you? How did he open your eyes?'

(John 9.26 - Latin and Greek)

It is possible that the rarity of the construction in the Latin New Testament can be caused by the influence of the Greek text: as is well known, Latin translations tried to stick as close as possible to the original (see e.g. Ceresa-Gastaldo 1975).

The history of Greek offers a very interesting picture. According to Havers (1911: 167-169), the dative external possessor construction had already started

6 Bauer (2000: 158) thinks that "The loss of the dativus sympatheticus is presumably related to the loss of the case system. This assumption is supported by evidence from languages where its use is still attested, such as German or Russian, which have case. Similarly in Modern French the structure is still used in pronominal, but not in nominal contexts: in contrast to nouns, pronouns still feature some case marking." This statement ignores the fact that in other Romance languages, such as Italian or Spanish, prepositional phrases with $a$ 'to' function as the dativus sympatheticus (e.g. Ho rotto una gamba a Giovanni 'I broke John's leg' while a similar sentence in French is hardly acceptable, see also Bally 1926 and Haspelmath 1999). 
declining during the classical time, and, as remarked above, was lost by the time of the New Testament. At the wake of the Byzantine age, the dative merged with the genitive in the paradigms of all nominal categories. In spite of this, in Modern Greek it is possible to distinguish between the dative and the genitive of enclitic pronouns, as the former takes the verb as its host, while the latter cliticizes to it head noun, as argued in König \& Haspelmath (1997: 555). Consider (35) and (36).

(35) $t u$ éspases to xéri

3SG.DAT break:PRT.2SG ART hand

(36) éspases to xéri tu

break:PRT.2S ART hand 3SG.GEN

'You broke his hand.' (Modern Greek)

In (35), the clitic $t u$ is hosted by the verb: this is the position of dative clitics, and this is also the normal way to convey the propositional content of the example. In (36), the same form is attached to the nominal head xéri 'hand', and functions as a genitive modifier. Thus, the dative external possessor construction which was lost before the disappearance of the dative case was recreated at a later time.

König \& Haspelmath (1997) and Haspelmath (1999) argue that the dative external possessor construction is an areal feature of the modern languages of Europe: in the first place, it is not limited to Indo-European languages, but also occurs in Basque, Maltese, Modern Hebrew, and Hungarian. Notably, at least in the Semitic languages, contact seems to have played a relevant role, as this construction does not occur in Classical Arabic or in Biblical Hebrew. In the second place, the construction does not occur in languages that are spoken at the margins of the European linguistic area, such as English and the Scandinavian languages, Celtic, Finnic languages, Turkish, and East Caucasian languages (Haspelmath 1999: 116). Remarkably, both Old English and Old Norse featured the construction in ancient times, as the other Germanic languages (Havers 1911: 299).

To sum up, the dative external possessor construction seems to be a rather unstable pattern: in the course of the attested history of Greek, for example, one can see its decay and its renewal. Changes are attested in other Indo-European languages: Old Hittite displays possessive pronouns, with the dative external possessor construction emerging during the Middle Hittite time, accompanied by the decay of possessive pronouns. In West Germanic the construction remained relatively stable over time, but it decayed in English 
and in North Germanic. In at least two of the non-Indo-European languages of Europe, it emerged, possibly because of language contact. In the Slavic languages, the construction remained stable over time. Remarkably, however, the attested history of these languages starts at a much later time than the attested history of Greek, Latin, and the non-European Indo-European languages (and the same can be said for West Germanic).

In the non-European Indo-European languages, the construction was soon lost, because of early merger of the dative and the genitive. In fact, this development, which started with clitic forms of personal pronouns, makes it difficult to gauge the extent to which the construction existed at all in these languages. In Sanskrit, syncretism affected only first and second person clitic pronouns, but this made it synchronically impossible to detect the construction, as such pronouns featured prominently in it in other languages. (Note further that both dative and genitive clitic forms occurred in P2 in Vedic Sanskrit, making it impossible to distinguish between them, as one can do in Modern Greek.) The construction did not even arise at a later time, as the dative and the genitive merged in Middle-Indo-Aryan. Viti (2004) argues that inalienable possession tended to be expressed via nominal composition in Vedic. In the case of pronominal possessors, Rosén (1989) shows that compounds such as mad-dehas 'my body' or tvat-putra 'your son' are the most frequent strategy for the encoding of inalienable possession in Classical Sanskrit. Such com-

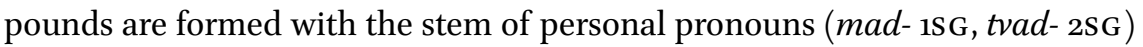
plus a noun. This stem, which only occurs in compounds, is also the base for derivation of a set of possessive adjectives, whose usage, however, remained limited in Sanskrit. Putative external possessors in the dative are not a feature of Classical Sanskrit: apparently, the morphological strategy of compounding replaced the syntactic strategy in the encoding of inalienable possession.

\subsection{Reconstructability of the Construction}

In Section 2.4 I have shown that the dative external possessor construction has been a quite unstable feature of the Indo-European languages over the centuries. In addition, it seems to be easily borrowed through contact. The interpretation of the data from ancient Indo-European languages is not as unambiguous as it is usually thought to be: among the oldest branches of Indo-European, only Greek and Latin, both from the same area, offer abundant evidence for the construction. Germanic and Balto-Slavic also provide good evidence, but these languages are attested much later, and have been in contact already in pre-literary times. Hittite, the most ancient attested Indo-European language, provides puzzling evidence: the construction does not occur in Old Hittite, but emerges immediately thereafter. The evaluation of the Indo-Aryan data 
is more complex than usually thought, but it is of crucial importance in order to rule out the possibility that the dative external possessor construction can really be reconstructed for Proto-Indo-European and is not an unstable feature of the Indo-European languages of Europe.

As we have seen in Section 2.1, first and second person pronouns cannot offer evidence for the existence of the dative external possessor construction in Vedic Sanskrit. Pronominal clitics, which only had a single form for the dativegenitive, did indeed derive from ancient Indo-European datives. However, as they were synchronically not analyzable as such, and since other nominal categories occurred in the genitive in the same construction, they could have been introduced into it on account of their genitive meaning. Evidence for dative external possessors is very scanty: Havers (1911: 30) mentions a passage in which the form túbhyam (2SG.DAT) occurs as dativus sympatheticus of type (ii). However, as Havers shows, the form táva (2SG.GEN) is also attested in a similar passage (cf. ib.), and with type (i) he mentions a number of occurrences of the accented genitive form mama (1SG.GEN). Is it possible to consider this single occurrence as evidence for the original form of the construction? The interpretation of the very limited number of other dative forms of pronouns and nouns in Havers' types (i)-(iii) is doubtful: as Havers argues, they can mostly be taken as beneficiary datives. The only type of dativus sympatheticus in which nominal categories other than first and second person pronouns occur is type (v). Notably, Vedic occurrences listed by Havers in this category do not seem to indicate possession in as clear a manner as those from other languages. Consider example (37).

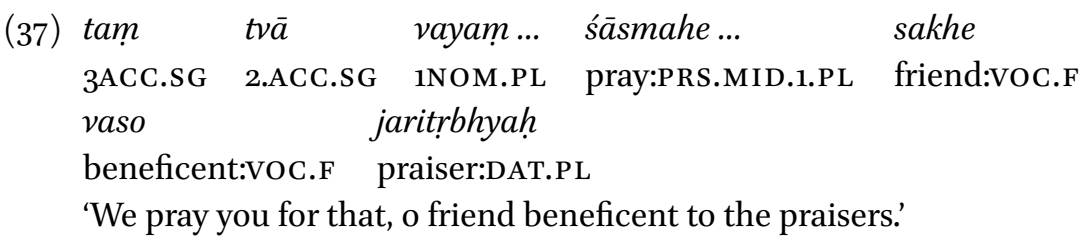

(RV 30.10 - Sanskrit)

In (37) the dative jaritrbhyah 'to the praisers' can easily be understood as a beneficiary dative. This difference becomes clear if we compare (37) with (8) from Homeric Greek: in (8) it is not said that Polyctor is a father for the speaker, but that he is his father. In (7) from Gothic one could also argue for a beneficiary interpretation of the dative. However, the occurrence of a genitive in the Greek original (pántōn 'of all') supports a possessor interpretation, as does the whole context: "But so shall it not be among you: but whosoever will be great among 
you, shall be your minister. And whosoever of you will be the chief, shall be servant of all." (Mark 10.44).

The beneficiary meaning of the dative, inherited from Proto-Indo-European, remains productive in Indo-Iranian, as far as one can see in the languages in which the dative has not merged with the genitive. However, in Sanskrit dative experiencers are less frequent than in many other ancient Indo-European languages, and apparently their occurrence is semantically restricted. Regarding Vedic, Dahl (2014) notes that dative experiencers are limited to positive situations, "while parallel predicates denoting a negative state of mind ... have a genitive-marked Experiencer argument in Early Vedic." This fact shows that dative experiencers share the features of the beneficiary role.

As I discussed in Section 2.3, the dative in external possessor constructions must be understood as an experiencer. Partial disconnection between the dative and the experiencer role may be the reason why the morphological merger of the dative with the genitive of clitic pronouns brought about the decay of the construction. In the meantime, the association of the genitive case with the possessor role on the one hand, and of the dative case with the beneficiary role on the other hand became stronger (notably, the preferred strategy for encoding experiencers in Vedic Sanskrit was the nominative case, see Dahl 2014). In this connection, it is also remarkable that Havers' type (vi) of dativus sympatheticus mostly feature a beneficiary. In particular, occurrences similar to (9) from Homeric Greek, in which the dative is an experiencer involved in a (negative) inchoative situation do not occur in Vedic, in accordance with Dahl's observation. All occurrences have a strong positive facet, and support a beneficiary reading, as in (38).

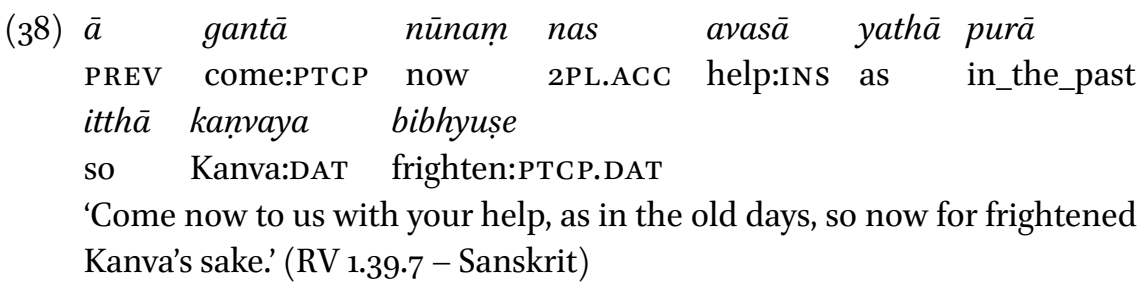

On account of the above remarks, the limited evidence offered by Vedic can be considered consistent with the reconstruction of the dative external possessor construction as belonging to Proto-Indo-European in general, and not only for the Indo-European languages of Europe; even so, it must be stressed that the Hittite evidence remains problematic. Concerning Vedic, the decay of the dativus sympatheticus can likely be considered one of the manifestations of 
ongoing marginalization of the dative, which lost, or never featured, a number of functions typical of the dative in other ancient Indo-European, languages: for example, the dative of agent with gerundives is attested in Vedic but was later was replaced by the instrumental (see Luraghi 2016), the dative of possession does not occur even in the oldest texts. In view of the increasing reduction of the functions of the dative in Sanskrit, the evidence offered by some dative accented forms of personal pronouns noted by Havers must be taken as preserving an ancient construction, thus they are valuable for reconstruction of Proto-Indo-European.

This construction has been referred to by different names: part and whole construction, partitive apposition (Hahn 1953, 1954), and, limited to Hittite and Armenian, case attraction (Luraghi 1993 and 2008). It is found in Greek, Armenian, and Anatolian; examples from Latin are limited and partly controversial while the remaining languages display no compelling evidence for it. Sporadic occurrences in Indo-Aryan point toward low entrenchment of the construction (Wiedmer 2014), and show notable difference with respect to Homeric Greek, as discussed in Section 3.3. Although the Armenian construction had long been recognized as due to language contact (see below Section 3.4), Hahn $(1953,1954)$ held double case to be the oldest way in which possession was expressed in Indo-European. More recently, Luraghi $(1990,1993)$ and Garrett (1990: 79-91) have argued that it was the outcome of a recent development in Anatolian as well. As I will show while reviewing the data, cases possibly featured in double case constructions change significantly depending on the language. As the double accusative in Homeric Greek is the best known and best described instantiation of double case construction, I start by illustrating its features in the next section.

\subsection{The Double Accusative in Homeric Greek}

The double accusative is widespread in Homeric Greek, occurring in cases of inalienable possession limited to body parts, feelings, and, in a small number of passages (four occurrences according to Jacquinod 1989: 25), pieces of a warrior's armor. ${ }^{7}$ An example has already been given in (2); further occurrences are (39) and (40).

7 Jacquinod also mentions one occurrence with an inanimate possessor, also featuring a partwhole relation; see further Luraghi \& Zanchi (2018: 15). 
(39) hé

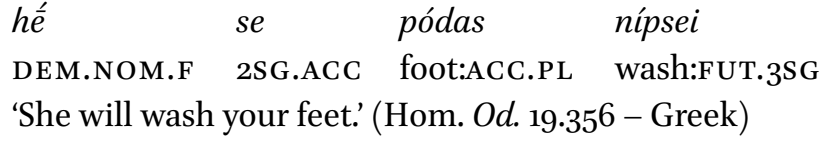

(40) hốs min érōs pukinàs phrénas amphekálupsen as 3SG.ACC desire:NOM wise:ACC.PL mind:ACC.PL roll_up:AOR.3SG 'Then love encompassed his wise heart.' (Hom. Il. 14.294 - Greek)

The double accusative, which is very frequent in Homeric Greek, is mostly limited to poetic style in later authors, most likely influenced by Homer. It corresponds to Havers' groups (i) and (ii): the four occurrences in which parts of an armor are referred to can also be included here, as the armor is understood as an integral part of the body of a fighting warrior. In some occurrences, the two constructions are used with the same verbs, as shown in Jaquinod (1989: 16). Thus we find occurrences such as tòn ... blápse phrénas '(a god) injured his (acc.) mind (acc.)' (Hom. Od. 14.178) with a double accusative, and blápse ... hoi ... goúnata '(he) injured his (dat.) knees (acc.)' (Hom. Il. 7.271), with a dative external possessor.

Hahn (1953) further mentions several passages that she claims provide evidence for other double case constructions. However, a closer examination shows that this is not the case: purported instances of double dative feature a dative external possessor and a locative expression in the dative, most often accompanied by a spatial particle, as in (41). Similarly, putative double genitives present a genitive possessor and a genitive second argument, as in (42).

(41) ménos dé hoi $\quad$ en phresi 1 thêke
courage:ACC PTC 3SG.DAT in heart:DAT put:AOR.3SG
'And (he) set courage in his heart.' (Hom. Il. 21.145-Greek)

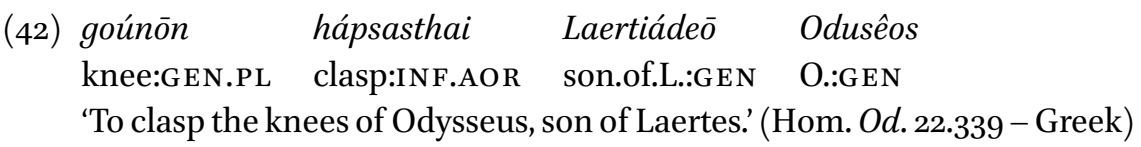

In (41), the dative hoi indicates the possessor, while the dative phresí in connection with the particle en denotes the endpoint of the trajectory indicated by the verb tithemi 'put'. This verb normally takes a direction complement in the dative, or with en plus dative (see Luraghi 2003: 83-84). In (42) again we find a possessor expression, this time in the genitive, Laertiádeō Odusêos. The genitive goúnōn is the second argument of the verb háptō, which always takes the genitive in Homeric Greek. 


\subsection{The Meaning of the Construction}

In this construction, we find transitive verbs that typically take accusative direct objects. The special feature here is that we find two accusative objects, one that indicates the possessor, and one that indicates a special type of possessee, that is, a part of the possessor. From the semantic point of view, we find two patients in this construction. Indeed, inalienable possession as instantiated here implies that both the possessee and the possessor are affected in the same way by the event: if I get injured in a part of my body, I myself get injured, and if desire gets hold of my mind, it gets hold of myself (see the discussion in Jacquinod 1989: 26-28 and the references therein). This is the reason why types of possessee in the double accusative construction are more limited than those that occur with the dative external possessor construction. Dative external possessors are affected when an event affects the entity that they possess inalienably. However, the type of affectedness is not necessarily the same. Kinship relations are a case in point: if one of my close relatives is injured, this certainly affects me, but it does not imply that I myself am injured.

Syntactically, the two accusative NPs in the double accusative construction have different status. The possessor NP displays the properties of a direct object, in that it can be passivized, while the possessee NP cannot, and also occurs in the accusative in passive sentences, as shown in (43) and (44).

$\begin{array}{lll}\text { blêto ... } & \text { knémen } & \text { dexiterén } \\ \text { hit:AOR.3SG.M/P } & \text { calf:ACC } & \text { right:ACC }\end{array}$

'He was wounded in his right leg.' (Hom. Il. 4.518-519- Greek)

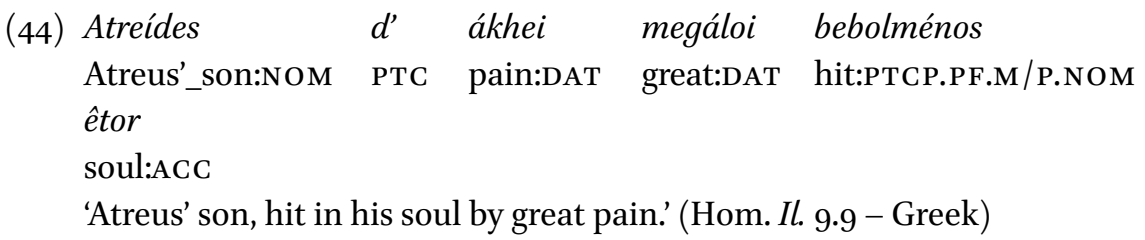

The possessee NP is syntactically in apposition to the possessor NP, and in the passive it takes an adverbial status. Such an appositional accusative also features in another construction, commonly known as 'Greek accusative' or 'accusative of respect'. It also often involves body parts. In Homer, it most frequently occurs with the indication of a quality of a person, and the body part to which this quality is especially referred, as in (45).

(45) pódas okùs Akhilleús

foot:ACC.PL swift:NOM Achilles:NOM

'Achilles swift-footed' (Homer, passim - Greek) 
Besides body parts, this type of appositional accusative occurs with nouns denoting moral qualities, bodily activities, shape, and measure or other inherent qualities (see Jacquinod 1989: 42-43). In later Greek, the last group of words became frequent. Examples are (46) and (47).

(46) phrourâs eteías mêkos watch:GEN yearly:GEN length:ACC 'A watch that has been lasting years.' (Aesch. Ag. 2 - Greek)

$\begin{array}{lllll}\text { diaphérei } & \text { he } & \text { gunè̀ } & \text { andròs } & \text { tè̀n } \\ \text { differ:PRS.3SG } & \text { ART.NOM } & \text { woman:NOM } & \text { man.GEN } & \text { ART.ACC } \\ \text { phúsin } & & & & \\ \text { nature:ACC } & & & & \end{array}$

'Women are different from men by their nature.' (Plato Rep. 453b - Greek)

It seems likely that the appositional accusative which originally occurred in double accusative possessive constructions later acquired the status of a special construction, in which it indicated the particular area of a referent to which a general predication applied. This special construction, which is a trademark of Ancient Greek syntax, does not occur in other ancient (or modern) Indo-European languages.

\subsection{Double Case in Other Ancient Indo-European Languages}

As remarked in Section 3, evidence for the double accusative constructions in other ancient Indo-European languages is hardly compelling. Jacquinod reviews a limited number of occurrences mentioned by Delbrück (1888), and concludes that the only convincing occurrence in Vedic is (48), which contains a noun that refers to an abstract property.
(48) aham
sahas ā
sahas
karam
1SG.NOM down-other:ACC strength:INS strength:ACC do:INJ.AOR.1SG 'I overcome another's strength with strength.' (RV X 49.8 - Sanskrit)

Note however that, as Jaquinod (1989: 59) also points out, several other interpretations have been suggested for this passage. Wiedmer (2014) surveys some other sporadic occurrences of double case in Vedic. As shown in (49), concrete nouns can also occur. 

(49) ahám etâñ... dvâa-dvā... indram yé 1SG.NOM DEM.ACC.PL two_by_two Indra:ACC REL.NOM.PL vájram yudháye ákrṇvata
mace:ACC.PL fight:INF make:IMPF.3PL
'I (struck down) by twos those who caused Indra's mace to fight.'

(Rigveda X 48.06)

In Vedic, this type of double accusative is very infrequent, but, in the meantime, it is not limited to body parts as it is in Greek (in fact, body parts do not occur at all): as shown in (48) and (49), featured nouns may refer to concrete or abstract entities. In addition to this, Wiedmer also discusses another type of double accusative, with verbs of depriving, in which however the two accusatives must be regarded as depending on the verb, since, as already discussed in Sections 2 and 2.3, verbs of depriving are bivalent predicates. Indeed, Wiedmer (2014: 33) points out that '[t]his type [is] syntactically clearly different from Ancient Greek.' Among other things, both arguments can be passivized, while in the Greek double accusative construction described in Sections 3.1 and 3.2 only the possessor noun can be passivized (Section 3.2). Wiedmer (2014: 22) also mentions sporadic occurrences of double locative. One of the few clear ones is $\left(5^{\circ}\right)$.

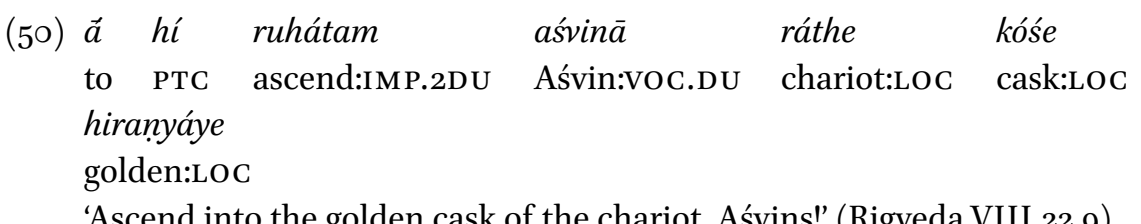

In (50), the NP kóse hiranyáye 'golden cask' indicates a part of the chariot (rátha-), and both are inflected in the locative. Notably, this pattern differs both from the pattern in (49) and from the pattern found in Homeric Greek, because the possessor is inanimate. (Wiedmer further cites an isolated occurrence from Avestan.)

The Latin evidence, which has been especially highlighted in Hahn (1954), boils down to a couple of examples in Plautus, which, however, can also be taken as left dislocated accusatives, a construction which is quite frequent in Latin informal discourse (Ernout \& Thomas 1959). Consider example (51): 

(51) hunc senem osse fini dedolabo assulatim DEM.ACC old.man:ACC bone:ABL end:ABL hew:FUT.1SG in.bits viscera entrails:ACC.PL 'This old fellow, I will hew to his very bone, (making) his entrails into mincemeat.' (Pl. Men. 858-859 - Latin)

In (51) hunc senem 'this old fellow' is the possessor of viscera 'entrails'. Syntactically, it seems better to analyze it as a hanging topic, rather than as the head noun of a phrase with an apposition.

A few other examples from later poetry, notably from Vergil, are better understood as stylistic imitations of Greek epic poetry. Hahn (1953) also mentions an alleged example of double ablative with instrumental meaning in Latin, shown in example (52):

\section{(52) dextera digitis rationem computat \\ right:ABL finger:ABL.PL calculation:ACC count:PRS.3SG \\ 'With (his) right (hand), he counts on (his) fingers.'}

(Pl. Mil. 203-205- Latin)

Hahn's translation reflects her assumption that dextera digitis must be taken as a partitive apposition: 'he counts using the finger of his right hand'. However, the context does not support this assumption. The opposition laevam manum ... dextera 'his left hand ... his right hand' rather points toward the correctness of the translation given in (52): ecce avortit; nixus laevo in femine habet laevam manum, dextera digitis rationem computat; ferit femur dexterum 'Look, he turns; he is leaning with his left hand on his left thigh, with his right hand he is counting on his fingers; he hits his right thigh.' (see Luraghi 1993 for further discussion). Finally, Jacquinod (1989: 6o) mentions a small number of occurrences from Middle High German, which could be taken as double accusatives but could also be interpreted in other ways, while Old High German does not contain traces of this construction. ${ }^{8}$

The adduced evidence shows different types of appositional constructions, with different properties and containing different types of nouns, rather than attesting to a pattern consistently reflected in the languages surveyed (i.e. the appositional constructions surveyed are not cognate).

8 Hahn (1969) also indicates the naming construction of the type räjā Nalo nāma 'a king, Nala (was) is name' (Sanskrit) as reflecting a partitive apposition. For a critical appraisal of this book, which was published posthumously, see Beekes (1973). 


\subsection{Case Attraction in Armenian and Hittite}

Double case constructions involving both the accusative and other cases are clearly and abundantly attested only in Armenian and in Hittite. Let us consider examples (53)-(56) from Armenian (examples $(54-56)$ are from Vogt 1932).

(53) $i$ mijoy cocoy kumē

from middle:ABL bossom:ABL POSS.2SG.ABL

'From the center of your heart.' (Psalms 73.11 - Armenian)

(54) $i \quad k n o j e ̂ \quad$ t'agaworēen

from wife:ABL.SG king:ABL.SG-ART

'By the wife of the king.' (Armenian)

(55) baznowt'eamb zawrawk'-n Hayoc

majority:INS troops:INS-ART Armenian

'With most of the Armenian troops (lit.: the majority of the troops).'

(Armenian)

(56) varowk' lawowt'eamb

life:INS.PL virtue:INS

'Through a virtuous way of life (lit.: a life of virtue).' (Armenian)

In (53) and (54) we find two occurrences of double ablative; the first occurrence features a part-whole relation between a referent (the heart) and one of its regions (the center), while in the second we find a kinship relation (the wife of the king). Examples (55) and (56) show two double instrumentals. Here, again, we find a part-whole relation in the first example (the majority of the troops), while the second indicates that a quality (virtue) is attributed to a certain referent (life).

As one can easily see from the examples, there are significant differences between the double case construction in Armenian and the double accusative construction in Homeric Greek, concerning both the semantics of the arguments and their morphological encoding. On the semantic plane, it must be remarked that, in the first place, inanimate possessors in Armenian are quite frequent in this construction. In the second place, types of possessee in the Armenian constructions are not limited to (body) parts, and the construction is not limited to part-whole relations, as shown by example (54). This example also shows that the two NPs involved need not have the same semantic role, as something which is done by the king's wife cannot be said to be done by 
the king. This is in contrast to the semantics of the Homeric double accusative construction (see Section 3.2). Moreover, on the plane of morphological encoding, it is important to note that double case constructions in Armenian only involve the ablative and the instrumental: there are no double genitives and, most notably, no double accusative to match the Homeric construction (see Caha 2013: 1023).

Some Hittite examples are (57)-(6o).

(57) takku LÚ.ULÙ' ${ }^{\mathrm{Lu}}$-an ELLAM KAxKAK= set if man:ACC free nose 3SG.POss.ACC kuiski waki INDF.NOM bite:PRS.3SG 'If someone bites a free men on his nose.' (Laws $§ 13$ (B i 33) - Hittite)

(58) $n u=z a \quad k e \quad$ KUR.KUR LÚKÚR INA MU 10.KAM CONN PTC DEM.ACC.PL countries enemy in year ten ammedaz ŠU-az tarahhun ISG.ABL hand:ABL conquer:PRT.1SG 'I conquered these enemy lands in ten years by my hand.'

( $A M{ }_{13} 6.45-46$ - Hittite)

(59) $n u=$ kan GAL-in arunan ${ }^{\mathrm{D}} \mathrm{Ku}(\mathrm{ma})$ rbiyaza É-irza... CONN PTC big:ACC sea:ACC Kumarbi:ABL house:ABL uwater $n=$ an INA É- $\check{S} U$ arha pehuter bring:PRT.3PL CONN 3SG.ACC into house his back bring:PRT.3PL 'They brought the big sea out of Kumarbi's house, and carried him to his (own) house.' (StBoT 14.11.16-19 - Hittite)

(6o) IŠTU HUR.sẬ̂Hahruwa tuedaz assiyantaza from Hahruwa_mountain 2SG.ABL love:PTCP.ABL 'From your beloved mountain Hahruwa.' (KUB 36.90.19 - Hittite)

Example (57) contains a double accusative (the nose of a free man). This occurrence is indeed similar to the Homeric Greek double accusative construction, in that it features a noun referring to a human being and one referring to a body part. However, the Hittite construction also shows differences with respect to the Homeric one, both on the semantic and on the morphological plane. Indeed, examples (58)-(6o) show double ablatives, and in fact the ablative case is frequent in this construction. The first example contains an ablative with instrumental function, again featuring a part-whole relation with a 
body part noun (my hand). Examples (59) and (6o) feature animate possessors with different type of possessee, the house in (59) and an external region (the mountains) in (6o). While examples (57) and (58) are evocative of the Homeric construction, (59) and (6o) show that in Hittite, too, types of possessee are not as restricted. In particular, while someone's house is likely to be categorized as an instance of inalienable possession, the occurrence of the name of a mountain in (6o) even casts doubts on the fact that the construction is really limited to inalienable possession.

While the rise of the Armenian construction has long been recognized as caused by influence from Georgian (see Vogt 1932 and the discussion below), Hittite examples of double case have been held by some scholars as representing the oldest Indo-European pattern, only later replaced by the adnominal genitive (see Hahn 1954: 199, Jacquinod 1989: 62-64). However, following the chronology of the texts it becomes apparent that double case is a later development in Hittite. In the first place, it must be remarked that examples as (57) and (59) could not date back to the $\mathrm{OH}$ period, since personal pronouns are never inflected in the ablative in Old Hittite. Indeed, even ablative forms of animate nouns such as ${ }^{\mathrm{D}} \mathrm{Ku}(\mathrm{ma})$ rbiyaza in (58) apparently never occur in Old Hittite original texts (see Starke 1977).

Double accusatives such as the one in (57) in principle could be possible in Old Hittite. However, the Old Hittite Corpus written in Old Script hardly offers evidence for such a hypothesis. On the contrary, comparing older with more recent versions of the Hittite Laws it becomes apparent that the double accusative has replaced the older construction with the possessor noun in the genitive co-indexed by a possessive enclitic pronoun (discussed in Section 2.1). In fact, example (61) is an older version of the same passage given above as example (57), which is taken from a post-Old Hittite copy of the Laws:

\begin{tabular}{|c|c|c|c|c|}
\hline $\begin{array}{l}\text { takku } \\
\text { if }\end{array}$ & $\begin{array}{l}\text { LÚ.ULÙ'LU-as } \\
\text { man:GEN }\end{array}$ & $\begin{array}{l}E L L A M-a s \\
\text { free:GEN }\end{array}$ & $\begin{array}{l}\text { KAxKAK= } \\
\operatorname{nose}(\mathrm{N})\end{array}$ & $\begin{array}{l}\text { set } \\
3^{\text {SG.POSS.ACC.N }}\end{array}$ \\
\hline kuiski & waki & & & \\
\hline DF.N & OM bite:PRs. & & & \\
\hline
\end{tabular}

In (61) the possessor noun is inflected in the genitive: this is the only available construction in Old Hittite original texts. The possessee takes the enclitic possessive adjective $=s e t$, which is a neuter accusative and indicates the direct object function. Note that this clitic also occurs in (57). This does not mean that possessive clitics were a feature of the double case construction: indeed they were not, and the occurrence of =set in (57) is a consequence of the copyist's partial updating of the text. Here, the copyist replaced the genitive with an 
accusative for the possessor noun, in order to introduce the new construction, but then forgot to leave out the possessive clitic, which was typical of the older construction.

As early as 1932, Vogt pointed out that agreement of head and modifier, generally called case attraction, in Classical Armenian must have developed under the influence of an Old Georgian pattern called suffix copying, as in example (62):

(62) šecevn-ita cmid-isa sameb-isa-jta

help-INS holy-GEN trinity-GEN-INS

'With the help of the Holy Trinity.' (from Boeder 1995: 159 - Georgian)

In (62) we find a head noun (help) inflected in the instrumental, and a genitive modifier (Holy Trinity). The modifier, after the genitive ending, also 'copies' the instrumental ending of the head noun. Notably, Georgian has agglutinating morphology, rather than the fusional type of the ancient Indo-European languages. With regard to the two types of construction, Vogt writes:

In Georgian the case ending of the head noun ... is repeated after all modifiers, either adjectives, pronouns, genitives, prepositional phrases or noun cases which already contain the expression of a case relation.... The difference between the two expressions [i.e. suffix copying in Georgian and double case in Armenian] consists in this, that Georgian allows cumulation of case endings whereas in Armenian the ending that marks the constituent forces away the ending that expresses the relation between head and modifier. Since the two languages have different [morphological] means, facts are not the same in detail. However, the general tendency of the two languages displays a striking similarity, making case endings also function as markers of noun phrases (1932: 75$) \cdot{ }^{9}$

In Luraghi (1993), (1994), and (2008) I have argued that the double case construction attested in Hittite is a borrowing from a neighboring language,

9 "En géorgien la desinence casuelle du nom déterminé ... se répète après tout déterminant, que ce soi un adjectif, un pronom, un génitif, une expression prépositionelle, ou encore un group pronominal comportant déjà l'expression de la relation casuelle.... La différence entre les deux expressions consiste en ceci, que le géorgien permet l'accumulation des désinences casuelles tandis qu'en arménien, la désinence marquant le group chasse la désinence marquant le rapport entre le déterminé et le déterminat. Comme les moyens dont disposent les deux langues sont différentes, le détail des faits n'est pas le meme. Les tendances générales des deux langues n'en montre pas moin une concordance frappante, en laissant les désinences casuelles servire aussi d'indicateurs des groupes nominaux". 
Hurrian, which also featured agglutinative morphology and suffix copying (see Wilhelm 1995), as shown in (63):
(63) $\operatorname{sen}(a)-i f f u-w e-n e-v a$ $\operatorname{torub}(i)-i-v a$
brother-my-GEN-ART.SG-DAT enemy-his-DAT
'To my brother's enemy.' (Mit. III 114 - Hurrian)

In practice, in the Armenian and Hittite double case constructions, nouns show a partly adjectival behavior, in that they are assigned case not based on their function, but as targets of agreement. In Hittite, personal pronouns go as far as agreeing in number with the head noun, thus becoming real possessive adjectives. An example is (64), which features a plural form of the second person singular pronoun:
(64) tuedas
assiyantas
pedas
2SG.DAT.PL love:PTCP.DAT.PL place:PTCP.DAT.PL
'In your favorite places.' (KUB 36.90.16 - Hittite)

According to Vogt, there is evidence, for example in the use of the article (examples 54 and 55) for assuming that the two nouns that occur in the Armenian case attraction construction belong to the same constituent. In other words, the noun denoting the possessor functions both morphologically and syntactically as an attributive adjective. Evidence from pronouns seems to point in the same direction for Hittite. Thus, the double case construction appears to be syntactically different from the Homeric Greek double accusative, in which the two accusative NPs remained independent, as shown by their behavior with regard to passivization. Therefore, the Homeric and the Hittite constructions do not appear to be cognate.

\subsection{Reconstructability of the Construction}

The evidence reviewed in the preceding sections does not support the reconstruction of a double case external possessor construction in Proto-IndoEuropean. Indeed, the comparative evidence shows that ancient Indo-European languages did not consistently feature this construction, either with the accusative or with other cases, the only exception being the Homeric Greek double accusative.

The Armenian and the Hittite double case constructions were later developments, independent of other Indo-European languages, and were both due to language contact. In both languages, double case constructions arose under the influence of partly similar constructions featured by non-Indo-European 
languages with agglutinating morphology. Their syntactic and semantic properties were different from those of the Homeric double accusative construction, and both historical and structural considerations indicate that, although superficially similar to one another, these constructions in the three languages were unrelated.

Thus, the Homeric Greek double accusative construction, despite being attested in one of the most ancient branches of the Indo-European language family, must be considered a language specific construction, rather than a piece of evidence for a Proto-Indo-European reconstruction.

In this article, I have analyzed two types of external possessor constructions occurring in ancient Indo-European languages: the dative external possessor construction, and the double case construction. For each of them, I reviewed the comparative data, and described the relevant semantic and syntactic properties. Both constructions have been considered to be of common Proto-Indo-European heritage by several scholars, even though the comparative data does not provide unambiguous evidence for either of them. In particular, the dative external possessor construction, which is today an areal feature of the languages of Europe, was more clearly attested in the European Indo-European languages already in antiquity. In spite of early merger of the dative and the genitive of pronominal clitics in Indo-Iranian languages, limited evidence from accented personal pronouns in Vedic attests to the antiquity of the construction. Concerning the double case construction, sizable and reliable evidence is provided only by three languages: Homeric Greek, Classical Armenian, and Middle and Late Hittite.

Based on the evidence, I suggest that only the former construction must date back to Proto-Indo-European, and that similar instantiations in the Indo-European languages actually provide pieces of evidence for its reconstruction, despite its early disappearance from the non-European Indo-European languages. The latter construction, in its turn, cannot be reconstructed. Double case constructions in Greek, Armenian, and Hittite have different syntactic and semantic properties, and arose from different historical backgrounds, while sporadic occurrences of double case in other languages do not reflect the construction attested in Homeric Greek. Hence, they should better be regarded as different constructions, independent of one another, rather than as reflexes of an original proto-construction. 


\section{Abbreviations}

a) Glosses

$1 \quad$ ist person

2 2nd person

3 3rd person

ABL ablative

ACC accusative

AOR aorist

ART article

C common gender

CONN connective

DAT dative

DEM demonstrative

DU dual

F feminine

FUT future

GEN genitive

IMP imperative

IMPF imperfect

INDF indefinite

INF infinitive

INJ injunctive

INS instrumental

LOC locative

\section{b) Sources}

Aesch. Aeschylus

Ag. Agamemnon

AM Mursilis' Annals

Caes. Caesar

Gal. The Gallic War

Hom. Homer

Il. The Iliad

KUB Keilschrift Urkunden aus

Bogazkoy
$\mathrm{M} / \mathrm{P}$ medio-passive

MID middle

N neuter

NEG negation

NOM nominative

OBL oblique

$\mathrm{P}$ passive

PF perfect

PL plural

Poss possessive

PREV preverb

PRS present

PRT preterite

PTC partiple

PTCP participle

REFL reflexive

REL relative

SBJ subjunctive

SG singular

suP supine

voc vocative

Men. Menaechmi

Mil. Miles Gloriosus

Mit. Mitanni letters

Od. The Odyssey

Pl. Plautus

Rep. The Republic

RV Rigveda

StBot Studien zu den Bogazkoy Texten 


\section{References}

Baldi, Philip. 2002. Inalienable Possession in Hittite and Proto-Indo-European. Donum Grammaticum: Studies in Latin and Celtic Linguistics in Honour of Hannah Rosén. ed. by Lea Sawicki \& Donna Shalev, 29-37. Louvaine-la-Neuve: Peeters.

Baldi, Philip \& Andrea Nuti. 2010. Possession in Latin. New Perspectives on Historical Latin Syntax, ed. by Philip Baldi \& Pierluigi Cuzzolin, vol. 3, 239-387. Berlin: Mouton de Gruyter.

Bally, Charles. 1926. L'expression des idées de sphère personnelle et de solidarité dans les langues Indo-européennes. Festschrift Louis Gauchat, ed. by Franz Fankhauser \& Jakob Jud, 68-78. Aarau: Verlag H. R. Sauerländer \& Co. [English translation: 1996. The Expression of Concepts of the Personal Domain and Indivisibility in Indo-European Languages. The Grammar of Inalienability, ed. by Hilary Chappell \& William McGregor, 31-61. Berlin/New York: Mouton de Gruyter.]

Bauer, Brigitte L. M. 2000. Archaic Syntax in Indo-European: The Spread of Transitivity in Latin and French. Berlin/New York: Mouton de Gruyter.

Beekes, R. S. P. 1973. Review of E. A. Hahn, Naming-Constructions in Indo-European Languages Cleveland: Press of Western Reserve University, 1969. Mnemosyne 26(4): 399-401.

Boeder, Winfried. 1995. Suffixaufnahme in Kartvelian. Double Case, ed. by Frans Plank, 151-215. Berlin/New York: Mouton de Gruyter.

Caha, Pavel. 2013. Explaining the Structure of Case Paradigms by the Mechanisms of Nanosyntax: The Classical Armenian Nominal Declension. Natural Language and Linguistic Theory 31(4): 1015-1066.

Ceresa-Gastaldo, Aldo. 1975. Il latino nelle antiche versioni bibliche. Roma: Studium.

Chappell, Hilary \& William McGregor. 1996. Introduction: Prolegomena to a Theory of Inalienability. The Grammar of Inalienability, ed. by Hilary Chappell \& William McGregor, 3-3o. Berlin/New York: Mouton de Gruyter.

Dahl, Eystein. 2014. The Morphosyntax of the Experiencer in Early Vedic. Perspectives on Semantic Roles, ed. by Silvia Luraghi \& Heiko Narrog, 181-204. Amsterdam/ Philadelphia: Benjamins.

Delbrück, Berthold. 1888. Altindische Syntax. Halle: Verlag der Buchhandlung des Waisenhauses.

Ernout, Alfred \& Francois Thomas. 1959. Syntaxe latine. Paris: Klincksieck.

Fried, Mirjam. 1999. From Interest to Ownership: A Constructional view of External Possessors. External Possession, ed. by Doris L. Payne \& Imanuel Barshi, 473-504. Amsterdam/Philadelphia: Benjamins. 
Gamkrelidze, Thomas \& Vjaceslav V. Ivanov. 1995. Indo-European and the IndoEuropeans: A Reconstruction and Historical Analysis of a Proto-Language and a Proto-Culture. Berlin/New York: Mouton de Gruyter.

Garrett, Andrew. 1998. Remarks on the Old Hittite Split Genitive. Mír Curad: Studies in Honor of Calvert Watkins, ed. by Jay Jasanoff, H. Craig Melchert \& Lisi Oliver, 155163. Innsbruck: Institut für Sprachwissenschaft der Universität Innsbruck.

Garrett, Andrew. 199o. The Syntax of Anatolian Pronominal Clitics. Ph.D. Diss., Harvard University.

Güterbock, Ans Gustav. 1983. Noch einmal die Formel parnaššea šuwaizzi. Orientalia Nuova Serie 52: 73-80.

Hahn, E. Adelaide. 1953. Vestiges of Partitive Apposition in Latin Syntax. TAPhA 82: 92-123.

Hahn, E. Adelaide. 1954. Partitive Apposition in Homer and the Greek Accusative. TAPhA 85: 197-289.

Hahn, E. Adelaide. 1969. Naming-Constructions in Some Indo-European Languages. Cleveland: Case Western Reserve University Press.

Haspelmath, Martin. 1999. External Possession in a European Areal Perspective. ed. by Payne, Doris L. \& Barshi, Immanuel, 109-135. External Possession. Amsterdam/ Philadelphia: Benjamins.

Haudry, Jean. 1977. L'emploi des cas en védique: Introduction à l'étude des cas en indoeuropéen. Lyon: Editions l'Hermès.

Havers, Wilhelm. 1911. Untersuchungen zur Kasussyntax der indogermanischen Sprachen. Strassburg, Trübner.

Heine, Bernd. 1997. Possession: Cognitive Sources, Forces and Grammaticalization. Cambridge: Cambridge University Press.

Jacquinod, Bernard. 1989. Le double accusatif en grec d'Homère à la fin du V siècle avant J.- $C$. Louvaine-la-Neuve: Peeters.

Kittilä, Seppo \& Fernando Zúñiga. 2010. Introduction: Benefaction and Malefaction from a Cross-Linguistic Perspective. Benefactives and Malefactives: Typological Perspectives and Case Studies, ed. by Seppo Kittilä \& Fernando Zúñiga, 1-28. Amsterdam/Philadelphia: Benjamins.

Kockelman, Paul. 20og. Inalienable Possession as Grammatical Category and Discourse Pattern. Studies in Language 33(1): 25-68.

König, Ekkehard \& Martin Haspelmath. 1997. Les constructions à possesseur externe dans les langues d'Europe. Actence et valence dans les langues d'Europe, ed. by J. Feuillet, 525-6o6. Berlin: Mouton - de Gruyter.

Luraghi, Silvia. 1986. Der semantische und funktionelle Bau des althethitischen Kasussystems. Zeitschrift fur vergleichende Sprachforschung 99: 23-42. 
Luraghi, Silvia. 199o. The Structure and the Development of Possessive Noun Phrases in Hittite. Historical Linguistics 1987 ed. by Henning Andersen \& Konrad Koerner, 309-324. Amsterdam/Philadelphia: Benjamins.

Luraghi, Silvia. 1993. La modificazione nominale in anatolico. Archivio Glottologico Italiano $78(2)$ : 144-166.

Luraghi, Silvia. 1994. Suffix Copying and Related Phenomena: A Prototype Approach. Linguistics 32: 1095-1108.

Luraghi, Silvia. 1997. Hittite. München/New Castle: Lincom Europa.

Luraghi, Silvia. 2008. Possessive Constructions in Anatolian, Hurrian, Urartean, and Armenian as Evidence for Language Contact. Anatolian Interfaces, ed by Billie J. Collins, Mary R. Bachvarova \& I. C. Rutherford, 147-155. Oakville, CT: Oxbow Press.

Luraghi, Silvia. 2016. The Dative of Agent in Indo-European Languages. STUF Language typology and Universals (Special Issue on Non-Central Usages of Datives) 69(1): 15-47.

Luraghi, Silvia \& Chiara Zanchi. 2018. Double Accusative Constructions and Ditransitives in Ancient Greek. Ditransitive Constructions in a Cross-Linguistic Perspective, ed. by A. Korn, C. Jahani \& A. Malchukov, 13-35. Wiesbaden: Reichert.

Malchukov, Andrej, Martin Haspelmath \& Bernard Comrie. 2010. Ditransitive Constructions: a Typological Overview. Studies in Ditransitive Constructions: A Comparative Handbook, ed. by Andrej Malchukov, Martin Haspelmath \& Bernard Comrie, 1-64. Berlin: Mouton de Gruyter.

Payne, Doris L. \& Immanuel Barshi. 1999. External Possession: What, Where, How, and Why. External Possession, ed. by Doris L. Payne \& Immanuel Barshi, 3-32. Amsterdam: Benjamins.

Roldán, Mercedes. 1972. Concerning Spanish Datives and Possessives. Language Sciences 21: 27-32.

Rosén, Haim. 1959. Die Ausdrucksform für 'veräusserlichen' und 'unveräusserlichen' im Frühgriechischen. Lingua 8: 264-295.

Rosen, Haim. 1989. A Marginal Note on Sanskrit Case Syntax. Hanjamana, ed. by Subhadra Kumar Sen, 33-39. Calcutta: University of Calcutta Press.

Starke, Frank. 1977. Die Funktionen der dimensionalen Kasus und Adverbien im Althethitischen. Wiesbaden: Harrassowitz.

Viti, Carlotta. 2004. Funzioni semantiche e pragmatiche nelle strategie di possesso dell'antico indiano. Archivio Glottologico Italiano 89: 41-83.

Vogt, Hans. 1932. Les groups nominaux en arménien et géorgien ancien. Norsk Tidsskrift for Sprogvidenskap 5: 57-81. 
Wiedmer, Paul. 2014. Partitivity and Part-Whole Constructions in Indo-European. Paper presented at the workshop Partitivity in Romance and Beyond, Zurich, 11-13 December 2014. 